\title{
MANAJEMEN KEPALA SEKOLAH DALAM MENINGKATKAN KINERJA GURU DI SDIT ISHLAHUL UMMAH KOTA SAWAHLUNTO
}

\author{
Hamadi \\ Madrasah Ibtidaiyyah Negeri 1 Kota Sawahlunto \\ Korespondensi: Jl. Paresen Desa Kumbayau Kecamatan Talawi \\ e-mail: hamadilimin@gmail.com
}

2000

\begin{abstract}
This study aims, to describe the principal's plan to improve teacher performance in SDIT Ishlatul Ummah, Sawablunto City, to describe the organization of principals in improving teacher performance at SDIT Ishlatul Ummah in Sawablunto City, to describe the implementation of principals in improving teacher performance in SDIT Ishlatul Ummah Kota Sawablunto, and to describe the supervision of the principal in improving teacher performance at SDIT Ishlatul Ummah in Sawablunto City. The research method is qualitative research with a case study method or approach. Research informants were 6 people. Data collection tools are researchers as key instruments and supporting instruments are interview guidelines, observation guidelines, field notes, and hand pone (HP). Data collection techniques are participatory observation, in-depth interviews and documentation studies. Data analysis techniques use the Miles and Huberman model which divides data analysis into three, namely data reduction, data presentation, and conclusion drawing. Data validity testing techniques using data triangulation and method triangulation. The results showed that starting from planning, organizing, implementing and supervising the principal program in improving teacher performance such as improving discipline, providing motivation, bolding teacher training in schools, supervising or supervising teacher performance, fostering teacher performance, and establishing cooperative relationships with teachers, it has been going well done by the school principal to improve teacher performance in achieving the educational goals at SDlab Ishlabul Ummah in Sawablunto City.
\end{abstract}

Keywords: Management, Principal, Teacher Performance

\section{PENDAHULAN}

Pendidikan sangat penting bagi kehidupan manusia, sebab melalui pendidikan segenap potensi yang dimiliki manusia termasuk ilmu pengetahuan akan dapat dikembangkan. Sebagai suatu kegiatan yang sadar akan tujuan pendidikan, maka dalam pelaksanaannya berada dalam suatu proses yang berkesinambungan dalam setiap jenis dan jenjang pendidikan, semuanya berkaitan dalam suatu sistem pendidikan yang integral. Pendidikan sebagai suatu sistem, tidak lain dari suatu totalitas fungsional yang terarah pada suatu tujuan. Suatu sub sistem yang ada dalam sistem tersusun dan tidak dapat dipisahkan dari unsur-unsur atau komponen yang 
berhubungan secara dinamis dalam suatu kesatuan.

Pendidikan menurut Undang-undang Nomor 20 tahun 2003 tentang Sistim Pendidikan Nasional (SPN), bab I pasal 1 adalah usaha sadar dan terencana untuk mewujudkan suasana belajar dan proses pembelajaran agar peserta didik secara aktif mengembangkan potensi dirinya untuk memiliki kekuatan spiritual keagamaan, pengendalian diri, kepribadian, kecerdasan, akhlak mulia, serta keterampilan yang diperlukan dirinya, masyarakat, bangsa dan negara (Departemen Agama RI, 2006: 5).

Sedangkan pendidikan nasional adalah pendidikan yang berdasarkan Pancasila dan Undang-Undang Dasar Nagara Republik Indonesia Tahun 1945 yang berakar pada nilai-nilai agama, kebudayaan nasional Indonesia dan tanggapan terhadap tuntutan perubahan zaman (Departemen Agama RI, 2006: 5).

Fungsi pendidikan nasional adalah mengembangkan kemampuan dan membentuk watak serta peradaban bangsa yang bermartabat dalam rangka mencerdaskan kehidupan bangsa. Sedangkan tujuan pendidikan nasional adalah untuk mengembangkan potensi peserta didik agar menjadi manusia yang beriman dan bertaqwa kepada Tuhan Yang Maha Esa, beraklak mulia, sehat, cakap, kreatif, mandiri, dan menjadi warga negara yang demokratis, serta bertanggung jawab (Departemen Agama RI, 2006: 5).

Tujuan pendidikan Islam menurut Herry dalam Ramayulis, (1994: 27) mengelompokan tujuan pendidikan Islam pada tujuan umum dan tujuan khusus. Tujuan umum menjadikan manusia sebagai abdi dan hamba Allah SWT yang senantiasa mengagungkan dan membesarkan Asma
Allah SWT dengan meneladani Rasulullah SAW, menjunjung tinggi ilmu pengetahuan suka mempelajari segala yang bermanfaat baginya dalam merealisasikan tujuan yang telah digariskan oleh Allah SWT.

Kepala sekolah merupakan pejabat profesional dalam mengelola organisasi sekolah sekaligus bertugas mengatur dan mengelola semua sumber, organisasi dan bekerjasama dengan komite sekolah, masyarakat, lembaga-lembaga lain serta stakebolder yang ada. Kepeminpinan kepala sekolah dalam mengembangkan dan mengelola sekolah harus memahami kebutuhan sekolah yang dipimpinnya termasuk kebutuhan guru, murid dan warga sekolah. Kepala sekolah profesional akan selalu memberi motivasi seluruh komponen sekolah untuk meningkatkan kompetensinya sehingga kompetensi warga sekolah dapat meningkat dan berkembang baik. Kepala sekolah dan guru sebagai tenaga kependidikan yang profesional tidak hanya menguasai bidang ilmu, bahan ajar, dan metode, akan tetapi mampu memotivasi peserta didik untuk memiliki keterampilan dan wawasan luas terhadap pendidikan.

Kepala sekolah adalah jabatan yang tidak bisa diisi oleh orang-orang tanpa didasarkan atas pertimbangan-pertimbangan. Siapa pun yang akan diangkat menjadi kepala sekolah harus ditentukan melalui prosedur serta persyaratan-persyaratan tertentu seperti: latar belakang pendidikan, pengalaman, usia, pangkat, dan integritas. (Wahjosumidjo, 2011: 84 ).

Sekolah Dasar Islam Terpadu (SDIT) Ishlahul Ummah Kota Sawahlunto merupakan suatu lembaga pendidikan tingkat Sekolah Dasar yang terletak di Tangsi Baru RT.03/II Kelurahan Tanah Lapang Kecamatan Lembah Segar Kota 
Sawahlunto, didirikan tahun 2004, Akreditasi A, berstatus sekolah swasta yang dikelola oleh Yayasan sebagai ketua Bapak Afdhal, SE, Pembina Bapak Riswan Putih dan Pengawas Bapak Drs. Basuki Wiwoho. Visi sekolah "Mewujudkan generasi Islam cerdas intelektual, emosional, dan spiritual yang kreatif unggul dan mandiri”. SDIT Ishlahul Ummah Kota Sawahlunto dipimpin oleh seorang kepala sekolah yaitu Ibuk Takwim, S.Pd.I dan memilik beberapa orang guru baik guru honor dan guru pegawai negeri sipil, dengan jumlah 17 orang yang terdiri dari 15 orang guru honor dan 2 orang guru pegawai negeri. Kemudian sarana dan prasarana SDIT Ishlahul Ummah Kota Sawahlunto sangat terbatas dibandingkan dengan Sekolah Dasar Negeri yang ada di Kota Sawahlunto, stratus tanah dan bangunan merupakan pinjam pakai dari PT. BA-UPO Sawahlunto. Namun SDIT Ishlahul Ummah Kota Sawahlunto mampu meraih berbagai jenis prestasi akademik maupun non akademik. (Observasi, Senin, 30 April 2018).

\section{KA] IANTEOR}

\section{Konsep Manajemen}

Kata manajemen berasal dari bahasa latin, yaitu kata manus dan agree yang berarti melakukan kata itu digabung menjadi kata kerja managere yang artinya menangani. Managere diterjemahkan dalam bahasa inggris dalam bentuk kata kerja to manage, dengan kata bendanya management, dan manajer untuk orang yang melakukan manajemen. Akhirnya manajemen diterjemahkan dalam bahasa Indonesia menjadi manajemen atau pengelolaan. (Husaini Usman, 2006: 3) Hasibuan, mendefenisikan manajemen adalah ilmu dan seni yang mengatur proses pemanfaatan sumber daya manusia dan sumber-sumber lainnya secara efektif dan efisien untuk mencapai suatu tujuan tertentu. (Malayu S.P Hasibuan, 1990: 3) Sedangkan menurut Terry yang dikutip oleh Hasibuan, (2006) mengartikan manajemen merupakan suatu proses yang terdiri dari tindakan-tindakan perencanaan, pengorganisasian, menggerakkan, dan mengendalikan, yang dilakukan untuk menentukan serta mencapai sasaran yang telah ditentukan melalui pemanfaatan sumber daya manusia dan sumber daya lainnya.

Berkaitan dengan itu, terdapat 3 pendapat berbeda; pertama mengartikan lebih luas dari pada manajemen (manajemen merupakan inti dari admistrasi); kedua, melihat manajemen lebih luas dari pada administrasi dan ketiga, pandangan yang menggangap bahwa manajemen identik dengan administrasi. Berdasarkan fungsi pokoknya istilah manajemen dan administrasi menpunyai fungsi yang sama karena itu perbedaan kedua istilah tersebut tidak konsisten dan tidak signifikan. (Mulyasa, 2012: 19)

\section{Kepala Sekolah}

Manajerial kepala sekolah berhubungan erat dengan keutuhan dan eksistensi sekolah, berusaha memahami kondisi tenaga pendidik dan kependidikan. Dalam menjalankan tugas tersebut ia tidak bisa mewujudkan tujuannya apabila kondisi kerja para guru tidak tertata dengan baik.

Keberhasilan suatu kegiatan atau pekerjaan tergantung dari manajemennya. Pekerjaan itu akan berhasil apabila manajemennya baik dan teratur, dimana manjemen itu sendiri merupakan suatu perangkat dengan melakukan suatu proses 
tertentu dalam fungsi yang terkait. Fungsi dari manajemen, dapat dijelaskan sebagai berikut: perencanaan, pengorganisasian, pelaksanaan, dan pengawasan (Echols dan Shadily, 1996: 97).

Secara etimologi menurut kamus besar bahasa Indonesia, Kepala Sekolah orang atau guru yang memimpin suatu sekolah. Dengan demikian kepala sekolah merupakan pihak yang ditunjuk untuk meminpin suatu lembaga pendidikan. Sedangkan secara terminologi, Wahjosumidjo, (2011: 91) mengemukan pengertian kepala sekolah adalah sebagai seorang tenaga profesional guru yang diberi tugas untuk memimpin suatu sekoalah dimana diselenggarakan proses belajar mengajar atau tempat dimana terjadi interaksi antara yang memberikan pelajaran dan murid yang menerima pelajaran. Sementara Asmendri, (2012: 15) mengungkapkan bahwa kepala sekolah adalah seorang guru (jabatan fungsional) yang diangkat untuk menduduki jabatan struktural (kepala sekolah) di sekolah. Berdasarkan beberapa pengertian di atas dapat disimpulkan bahwa kepala sekolah adalah seorang guru yang mempunyai kemampuan untuk memimpin segala sumber daya yang ada di sekolah, sehingga dapat didayagunakan secara maksimal untuk mencapai tujuan bersama.

\section{Kinerja}

Istilah kinerja berasal dari kata job performance atau actual perfoermance artinya prestasi kerja atau prestasi sesungguhnya yang dicapai oleh seseorang. Kinerja merupakan terjemahan dari bahasa Inggris, work performance atau job peformance. Kinerja dalam bahasa Indonesia disebut juga prestasi kerja. Kinerja atau prestasi kerja diartikan sebagai ungkapan kemampuan yang didasari oleh pengetahuan, sikap, keterampilan dan motivasi dalam menghasilkan sesuatu.

Kinerja merupakan kegiatan yang dijalankan oleh tiap-tiap individu dalam kaitannya untuk mencapai tujuan yang sudah direncanakan. Berkaitan dengan hal tersebut terdapat beberapa definisi mengenai kinerja. Smith dalam (Mulyasa, 2012: 136) menyatakan bahwa kinerja adalah output drive from processes, buman or otherwise. Kinerja merupakan hasil atau keluaran dari suatu proses. Dikatakan lebih lanjut oleh Mulyasa bahwa kinerja atau performance dapat diartikan sebagai prestasi kerja, pelaksanaan kerja, pencapaian kerja, hasil-hasil kerja atau unjuk kerja.

\section{METODE PENEUTAN}

Jenis penelitian ini adalah penelitian studi kasus. Studi kasus termasuk dalam penelitian analisis deskriptif, yaitu penelitian yang dilakukan terfokus pada suatu kasus tertentu untuk diamati dan dianalisis secara cermat sampai tuntas. Kasus yang dimaksud bisa berupa tunggal atau jamak, misalnya berupa individu atau kelompok. Disini perlu dilakukan analisis secara tajam terhadap berbagai faktor yang terkait dengan kasus tersebut sehingga akhirnya akan diperoleh kesimpulan yang akurat (Sutedi, 2009: 61).

Dalam penelitian kualitatif instrumen penelitian adalah peneliti sendiri yang menjadi instrumen kunci atau utama yang mengumpulkan data berdasarkan kriteriakriteria yang dipahami. Instrumen pendukung pada penelitian ini adalah menggunakan pedoman observasi dan pedoman wawancara serta alat lainnya. Sumber data dalam penelitian ini ada 6 orang dengan mengunakan teknik pengumpulan data 
yaitu: observasi, wawancara dan dokumentasi.

Dalam analisis data dalam penelitian mengikuti model yang dilakukan oleh Spradley dalam Sugiyono, (2012) membagi analisis data dalam penelitian kualitatif berdasarkan tahap - tahap seperti: analisis domain, analisis taksonomi, analisis komponensial, dan analisis tema kultural.

\section{HASIL DANPEMBAHASAN}

\section{Hasil Penelitian}

\section{a. Bentuk Perencanaan dalam Meningkatkan Kinerja Guru di SDIT Ishlahul Ummah}

Perencanaan merupakan rangkaian kegiatan pertama dalam proses manajemen, tidak terkecuali dalam meningkatkan kinerja guru. Perencanaan kinerja guru merupakan tindakan untuk masa yang akan datang demi tercapainya visi dan misi suatu sekolah. Perencanaan kinerja guru merupakan bagian dari alur proses manajemen dalam menentukan pergerakan sumber daya manusia (guru), dari posisi saat ini menuju posisi yang diinginkan dimasa depan. Sebagaimana yang diungkapkan oleh P1 selaku kepala sekolah di SDIT Ishlahul Ummah Kota Sawahlunto, mengatakan bahwa: Terkait dengan perencanaan yang lakukan oleh kepala sekolah dalam meningkatkan kinerja guru di SDIT Ishlahul Ummah Kota Sawahlunto sebagai berikut:

1) Meningkatkan kedisiplinan

Kepala sekolah merencanakan meningkatkan disiplin waktu, seperti waktu datang ke sekolah dan pulang sekolah. Waktu datang ke sekolah, jam 07.00 guru sudah berada di lingkungan sekolah dan jam 07.15 guru mem- bimbing siswa dalam kegiatan sebelum proses pembelajaran dimulai, seperti penyuluhan UKS, membaca asmual husna, membaca surat-surat pendek dan lagu-lagu nasional.

2) Memberikan motivasi

Motivasi merupakan proses psikis yang mendorong orang untuk melakukan sesuatu. Rutinitas pekerjaan sering menimbulkan kejenuhan yang mendalam yang dapat menurunkan motivasi berprestasi, yang diperparah oleh kondisi kerja yang tidak mendukung.

3) Mengadakan pelatihan guru di sekolah

Kepala sekolah merencanakan mengadakan pelatihan di sekolah seperti worshop, lokakarya. Pelatihan direncanakan diikuti seluruh guru yang kegiatannya dilaksanakan setiap tahun, sebelum tahun pelajaran dimulai.

4) Pengawasan atau supervisi kinerja guru

Di dalam pengawasan kinerja guru kepala sekolah melakukanya dengan cara melakukan kunjungan kelas secara langsung disaat proses kegiatan belajar mengajar berlangsung, meskipun tidak semua guru dikunjungi kelasnya, untuk guru-guru yang telah dianggap bagus dalam kegiatan mengajar tidak di awasi lagi.

5) Pembinaan kinerja guru

Dalam hal ini biasanya dari pihak yayasan, komite ataupun kepala sekolah berkoordinasi dengan Dinas Pendidikan untuk peningkatan kurikulum yang ada, apabila ada kurikulum yang baru, maka akan diterapkan di sekolah, hal ini tentunya ditunjang dengan fasilitasfasilitas yang selalu dimonitoring oleh pihak sekolah.

6) Menjalin hubungan kerja sama dengan guru 
Terbinanya hubungan kerjasama yang baik antara kepala sekolah dengan guru, maka tujuan sekolah dapat dicapai dengan mudah. Berdasarkan hasil wawancara dengan kepala sekolah. Penulis memperoleh gambaran dalam hal menjalin hubungan kerjasama dengan guru kepala sekolah SDIT Ishlahul Ummah Kota Sawahlunto menganggap guru-guru dan pegawai sebagai mitra kerja bahkan sebagai teman.

\section{b. Bentuk Pengorganisasian dalam} Meningkatkan Kinerja Guru di SDIT Ishlahul Ummah Kota Sawahlunto.

1) Rekrutmen guru yaitu Dalam peningkatan kinerja guru di SDIT Ishlahul Ummah Kota Sawahlunto, diawali dari rekrutmen guru. Guru yang diterima sebagai tenaga pendidik di SDIT Ishlahul Ummah Kota Sawahlunto, dengan ktiteria sebagai berikut: bertaqwa kepada Allah SWT, pendidikan minimal Strata Satu (S.1), memiliki komitmen yang kuat, memiliki motivasi yang tinggi, berakhlak mulia, loyalitas kepada pimpinan, serta mampu membaca al-qur'an.

2) penempatan guru sesuai kompetensi yaitu penempatan guru sesuai dengan kompetensi dan latar belakang pendidikan sangat penting direncanakan kepala sekolah, seperti guru yang memiliki kompetensi, kinerja bagus dan motivasi yang tinggi tempatkan sebagai guru kelas I karena mengajarkan dasardasar dalam pendidikan dan guru kelas VI untuk menentukan mutu pendidikan melalui lulusan yang berkualitas.

3) penempatan guru sebagai pembina kegiatan ekstrakurikuler yaitu kegiatan Dramband dibina oleh guru kesenian, kepramukaa dibina oleh pembina pramuka yang telah mengikuti minimal Kursus Mahir Dasar (KMD), kegiatan Olimpiade Seni dan Olahraga Nasional (O2SN) dibina oleh guru Pendidikan Jasmani, Olahraga dan Kesehatan (PJOK) serta guru Seni Budaya dan Keterampilan (SBK), kegiatan Tahfiz dibina oleh guru Pendidikan Agama Islam PAI), Bahasa Inggris dibina oleh guru Bahasa Inggris dan Bahasa Arab dibina guru yang Bahasa Arab.

\section{c. Bentuk Pelaksanaan dalam Meningkatkan Kinerja Guru di SDIT Ishlahul Ummah Kota Sawahlunto.}

Pelaksanaan kerja merupakan aspek terpenting dalam fungsi manajemen karena merupakan pengupayaan berbagai jenis tindakan itu sendiri, agar semua anggota kelompok mulai dari tingkat teratas sampai terbawah berusaha mencapai sasaran organisasi sesuai dengan rencana yang ditetapkan semula, dengan cara yang baik dan benar. Terkait dengan upaya yang saya lakukan dalam meningkatkan kinerja guru di SDIT Ishlahul Ummah sebagai berikut:

1) Meningkatkan kedisiplinan

Kepala sekolah merencanakan meningkatkan disiplin waktu, seperti waktu datang ke sekolah dan pulang sekolah. Waktu datang ke sekolah, jam 07.00 guru sudah berada di lingkungan sekolah dan jam 07.15 guru membimbing siswa dalam kegiatan sebelum proses pembelajaran dimulai, seperti penyuluhan UKS, membaca asmual husna, membaca surat-surat pendek dan lagu-lagu nasional.

2) Memberikan motivasi

Motivasi merupakan proses psikis yang mendorong orang untuk melakukan 
sesuatu. Rutinitas pekerjaan sering menimbulkan kejenuhan yang mendalam yang dapat menurunkan motivasi berprestasi, yang diperparah oleh kondisi kerja yang tidak mendukung.

3) Mengadakan pelatihan guru di sekolah

Kepala sekolah merencanakan mengadakan pelatihan di sekolah seperti worshop, lokakarya. Pelatihan direncanakan diikuti seluruh guru yang kegiatannya dilaksanakan setiap tahun, sebelum tahun pelajaran dimulai.

4) Pengawasan atau supervisi kinerja guru

Di dalam pengawasan kinerja guru kepala sekolah melakukanya dengan cara melakukan kunjungan kelas secara langsung disaat proses kegiatan belajar mengajar berlangsung, meskipun tidak semua guru dikunjungi kelasnya, untuk guru-guru yang telah dianggap bagus dalam kegiatan mengajar tidak di awasi lagi.

5) Pembinaan kinerja guru

Dalam hal ini biasanya dari pihak yayasan, komite ataupun kepala sekolah berkoordinasi dengan Dinas Pendidikan untuk peningkatan kurikulum yang ada, apabila ada kurikulum yang baru, maka akan diterapkan di sekolah, hal ini tentunya ditunjang dengan fasilitasfasilitas yang selalu dimonitoring oleh pihak sekolah.

6) Menjalin hubungan kerja sama dengan guru

Terbinanya hubungan kerjasama yang baik antara kepala sekolah dengan guru, maka tujuan sekolah dapat dicapai dengan mudah. Berdasarkan hasil wawancara dengan kepala sekolah. Penulis memperoleh gambaran dalam hal menjalin hubungan kerjasama dengan guru kepala sekolah SDIT Ishlahul
Ummah Kota Sawahlunto menganggap guru-guru dan pegawai sebagai mitra kerja bahkan sebagai teman.

\section{d. Bentuk Pengawasan dalam Mening- katkan Kinerja Guru di SDIT Ishlahul Ummah Kota Sawahlunto.}

Pengawasan yang dilakukan kepala sekolah dalam meningkatkan kinerja guru di SDIT Ishlahul Ummah Kota Sawahlunto yaitu:

1) Pengawasan kedisiplinan.

Pengawasan terhadap kedisiplinan kehadiran dilakukan kepala sekolah dengan cara mencek kehadiran guru dalam bentuk laporan bulan. Guru dicek berapa hari kehadiran, berapa hari izin, berapa kali terlambat datang dan cepat pulang melalui daftar hadir guru dan pegawai. Dan pengawasan terhadap perangkatan pembelajaran, kepala sekolah selalu mencek berapa orang guru yang membuat perangkat pembelajaran, berapa orang yang tepat waktu mengumpulkannya dan berapa orang yang belum melengkapi perangkat pembelajaran.

2) Pengawasan motivasi.

Kepala sekolah selalu mengawasi bagaimana motivasi guru dalam mengajar. Apakah memiliki motivasi yang tinggi atau rendah. Guru yang memiliki motivasi tinggi diberikan riword sedangkan guru yang memiliki motivasi rendah diberikan fanisment.

3) Pengawasan pelatihan guru di sekolah.

Pengawasan yang dilakukan kepala sekolah bagi guru yang mengikuti pelatihan yang dilakukan di sekolah, selesai pelatihan guru diharapkan untuk membuat laporan kegiatan. Dan guru yang diutus mengikuti pelatihan di luar sekolah seperti yang diadakan oleh dinas 
pendidikan, maka guru diminta membuat laporan kegiatan yang diikutinya.

4) Pengawasan supervisi kinerja guru.

Supervisi kinerja guru yang direncanakan oleh kepala sekolah dilakukan minimal satu kali dalam semester sebagaimana program dan jadwal supervisi. Pengawasan supervisi kinerja guru dituangkan dalam bentuk Sasaran Kinerja Pegawai (SKP) yang dibuat setiap tahun, SKP dimulai Januari s.d Desember tahun berjalan.

5) Pengawasan pembinaan kinerja guru.

Dalam hal ini biasanya dari pihak yayasan, komite ataupun kepala sekolah berkoordinasi dengan Dinas Pendidikan untuk peningkatan kurikulum yang ada, apabila ada kurikulum yang baru, maka akan diterapakan di sekolah, hal ini tentunya ditunjang dengan fasilitasfasilitas yang selalu dimonitoring oleh pihak sekolah.

6) Pengawasan hubungan kerjasama dengan guru.

Terbinanya hubungan kerjasama yang baik antara kepala sekolah dengan guru, maka tujuan sekolah dapat dicapai dengan mudah. Berdasarkan hasil wawancara dengan kepala sekolah. Penulis memperoleh gambaran dalam hal menjalin hubungan kerjasama dengan guru kepala sekolah SDIT Ishlahul Ummah Kota Sawahlunto menganggap guru-guru dan pegawai sebagai mitra kerja bahkan sebagai teman.

\section{Pembahasan}

1) Meningkatkan Kedisiplinan

Kepala sekolah merencanakan meningkatkan disiplin waktu, seperti waktu datang ke sekolah dan pulang sekolah. Waktu datang ke sekolah, jam 07.00 guru sudah berada di lingkungan sekolah dan jam 07.15 guru membimbing siswa dalam kegiatan sebelum proses pembelajaran dimulai, seperti penyuluhan UKS, membaca asmual husna dan membaca surat-surat pendek dan lagu-lagu nasional. Kemudian disiplin waktu pulang, sebelum pembelajaran selesai guru belum dibenar pulang, maka waktu pulang adalah jam 15.00. Kedisiplinan diawal dari kepala sekolah, maka kepala sekolah sebelum jam 07.00 sudah hadir di sekolah.

Disiplin dalam membuat perangkat pembelajaran seperti RPP, media pembelajaran, kepala sekolah merencanakan sebelum tahun pelajaran dimulai, seluruh perangkat guru sudah siap. Pengumpulan perangkat pembelajaran disepakati oleh guru dan dikuatkan kepala sekolah. Bahkan, guru yang disiplin sudah dikumpulkan di ruang kepala sekolah sebelum tanggal yang telah ditetapkan.

Kedisiplinan sangat diperlukan dalam setiap pekerjaan, terutama disiplin waktu. Adanya kedisiplinan diharapkan dapat meningkatkan kinerja guru sebagaimana dikatakan oleh Ibuk Takwim selaku kepala sekolah di SDIT Ishlahul Ummah Kota Sawahlunto, saya mencoba untuk membangkitkan kedisiplinan dari sejak saya memimpin di sekolah ini, dengan memulai dari diri saya sendiri. Saya berusaha datang ke sekolah kurang dari jam 7, dengan harapan dapat dicontoh oleh para staf dan para siswa. Bagi guru yang jam pelajarannya lebih dari jam 7 atau mempunyai jam pelajaran agak siang saya

110 Jurnal al-Fikrah, Vol. VI, No. 2 Juli-Desember 2018 
mengharapkan mereka dapat disiplin waktu pada saat mulai dan mengakhiri pelajaran di kelas.

Papalia (2014: 291) menjelaskan disiplin adalah cara untuk membentuk karakter seseorang dan mendidik untuk melatih kontrol diri dan terikat kepada prilaku bisa diterima masyarakat.

2) Memberikan Motivasi.

Motivasi merupakan proses psikis yang mendorong orang untuk melakukan sesuatu. Rutinitas pekerjaan sering menimbulkan kejenuhan yang mendalam yang dapat menurunkan motivasi berprestasi, yang diperparah oleh kondisi kerja yang tidak mendukung. Motivasi yang dilakukan oleh kepala sekolah dalam meningkatkan kinerja guru ada dua yaitu: motivasi langsung dan motivasi tidak langsung, kalau motivasi langsung dengan cara pemberian piagam penghargaan dan hadiah berupa uang tunai, yang diberikan kepada guru kelas VI karena keberhasilan dalam memcapai nilai nasional (UN) tertinggi ditingkat Kota Sawahlunto, sedangkan motivasi tidak langsung dengan cara kata-kata pujian, ucapan terima kasih yang mampu membangkitkan semangat kerja gurugurunya di SDIT Ishlahul Ummah Kota Sawahlunto.

Motivasi adalah pendorong, suatu usaha yang disadari untuk mempengaruhi tingkah laku seseorang agar tergerak hatinya untuk bertindak melakukan sesuatu sehingga mencapai hasil atau tujuan tertentu (Purwanto, 2010: 71).

3) Mengadakan Pelatihan Guru di Sekolah.

Kepala sekolah merencanakan mengadakan pelatihan di sekolah seperti worshop, lokakarya. Pelatihan direncanakan diikuti seluruh guru yang kegiatannya dilaksanakan setiap tahun, sebelum tahun pelajaran dimulai. Materi pelatihan di antaranya menyusun Dokumen I, membuat perangkat pembelajaran. Di samping mengadakan pelatihan guru di sekolah, kepala sekolah juga merencanakan, mengutus guru untuk mengikuti pelatihan yang diadakan oleh Dinas Pendidikan, seperti pelatihan penyempurnaan kurikulum 2013.

Mengadakan pelatihan guru merupakan langka baik juga dilakukan kepala sekolah SDIT Ishlahul Ummah Kota Sawahlunto untuk meningkatkan kinerja guru, seperti pelatihan kurikulum 2013, yang pesertanya seluruh guru, sedangkan waktu pelaksanaannya di bulan Juni setiap tahun pelajaran, kegiatan ini dibiayai oleh dana yayasan dengan tujuan untuk meningkatkan kinerja guru.

Kamil, (2010: 6) berpendapat menfinisika pelatihan sebagai usaha sistematis untuk menguasai keterampilan, peraturan, konsep, atau pun cara berprilaku yang berdampak pada peningkatan kinerja.

4) Pengawasan atau Supervisi Kinerja Guru.

Didalam pengawasan kinerja guru kepala sekolah melakukanya dengan cara melakukan kunjungan kelas secara langsung disaat proses kegiatan belajar mengajar berlangsung, meskipun tidak semua guru dikunjungi kelasnya, untuk guru-guru yang telah dianggap bagus dalam kegiatan mengajar tidak di awasi lagi. Dengan melakukan kunjungan kelas kepala sekolah bisa secara langsung mengawasi jalanya kegiatan belajar 
mengajar yang dilakukan oleh guru, sedangkan kunjungan ini dilakukan oleh kepala sekolah minimal 1 kali dalam semester. Supervisi kelas merupakan tugas pokok dan fungsi (tupoksi) kepala sekolah, dengan tujuan untuk melihat kemampuan yang dimiliki oleh guru dalam menyampaikan pembelajaran di kelas.

Pengawasan adalah segenap kegiatan untuk meyakinkan dan menjamin bahwa tugas atau perkerjaan telah dilakukan sesuai dengan rencana yang telah ditetapkan (Siagian, 2003: 112).

5) Pembinaan Kinerja Guru.

Dalam hal ini biasanya dari pihak yayasan, komite ataupun kepala sekolah berkoordinasi dengan Dinas Pendidikan untuk peningkatan kurikulum yang ada, apabila ada kurikulum yang baru, maka akan diterapakan di sekolah, hal ini tentunya ditunjang dengan fasilitasfasilitas yang selalu dimonitoring oleh pihak sekolah. Kepala sekolah selalu memberikan pembinaan terhadap para guru demi memperbaiki kinerja para gurunya, sekali dalam sebulan kemudian bentuk pembinaan yang dilakukan seperti: disiplin kehadiran, pelaksanaan tugas, kerja sama, tata tertib guru, dan komunikasi, sehingga tujuan pendidikan bisa tercapai dengan baik.

Pembinaan adalah upaya pendidikan formal dan non formal yang dilakukan secara sadar, berencana, terarah, teratur, dan bertanggung jawab dalam rangkah memperkenalkan, menumbuhkan, membimbing, dan mengembangan suatu dasar-dasar kepribadiannya seimbang (Pasaribu, 1990: 84).
6) Menjalin Hubungan Kerjasama dengan Guru.

Terbinanya hubungan kerjasama yang baik antara kepala sekolah dengan guru, maka tujuan sekolah dapat dicapai dengan mudah. Berdasarkan hasil wawancara dengan kepala sekolah. Penulis memperoleh gambaran dalam hal menjalin hubungan kerjasama dengan guru kepala sekolah SDIT Ishlahul Ummah Kota Sawahlunto menganggap guru-guru dan pegawai sebagai mitra kerja bahkan sebagai teman. Mempunyai prinsip selain rasa kekeluargaan juga tidak ada istilah atasan dan bawahan, yang ada adalah teman seperjuangan dalam rangka mencerdaskan anak bangsa. Kepala sekolah memberi saran terkadang lewat bercanda agar guru merasa tidak tersinggung dan apabila ada permasalahan curhat dan berbincangbincang di ruangan para guru serta saling memberi masukan satu sama lain, seperti: menanyakan kondisi guru, menjalin silaturrahmi, dan mengunjungi guru yang ditimpa musibah.

Perencanaan adalah sebuah proses perdana ketika hendak melakukan pekerjaan baik dalam bentuk pemikiran maupun kerangka kerja agar tujuan yang hendak dicapai mendapatkan hasil yang optimal. Menurut F. E. Kast dan Rosenzweig dalam Syafiie, (2011) perencanaan adalah suatu kegiatan yang terintegrasi yang bertujuan untuk memaksimalkan efektifitas keseluruhan usaha-usaha, sebagai suatu sistem sesuai dengan tujuan organisasi yang bersangkutan. Fungsi perencanaan antara lain untuk menetapkan arah dan setrategi serta titik awal kegiatan agar dapat membimbing serta memperoleh ukuran 
yang dipergunakan dalam pengawasan untuk mencegah pemborosan waktu dan faktor produksi lainnya.

\section{PENUTUP}

\section{Kesimpulan}

Berdasarkan hasil penelitian tentang manajemen kepala sekolah dalam meningkatkan kinerja guru di SDIT Ishlahul Ummah Kota Sawahlunto, dapat disimpulkan sebagai berikut:

1) Perencanaan Kepala Sekolah dalam Meningkatkan Kinerja Guru SDIT Ishlahul Ummah Kota Sawahlunto, misalnya meningkatakan kedisiplinan, memberikan motivasi, mengadakan pelatihan guru di sekolah, pengawasan atau supervisi kinerja guru, pembinaan kinerja guru, serta menjalin hubungan kerjasama dengan guru.

2) Pengorganisasian Kepala Sekolah dalam Meningkatkan Kinerja Guru SDIT Ishlahul Ummah Kota Sawahlunto, sebagai berikut: rekrutmen guru, penempatan guru sesuai kompetensi, dan penempatan guru sebagai pembina kegiatan ekstrakurikuler.

3) Pelaksanaan Kepala Sekolah dalam Meningkatkan Kinerja Guru SDIT Ishlahul Ummah Kota Sawahlunto, sebagai berikut: meningkatakan kedisiplinan, memberikan motivasi, mengadakan pelatihan guru di sekolah, pengawasan atau supervisi kinerja guru, pembinaan kinerja guru, serta menjalin hubungan kerjasama dengan guru.

4) Pengawasan Kepala Sekolah dalam Meningkatkan Kinerja Guru SDIT Ishlahul Ummah Kota Sawahlunto, sebagai berikut: pengawasan kedisiplinan, pengawasan motivasi, pengawasan pelatihan guru di sekolah. pengawasan supervisi kinerja guru, pengawasan pembinaan kinerja guru, pengawasan hubungan kerjasama dengan guru.

\section{Saran}

Berdasarkan hasil penelitian dan analisis di bab sebelumnya, peneliti perlu memberikan beberapa saran:

1. Kepala sekolah SDIT Ishlahul Ummah Kota Sawahlunto diharapkan untuk selalu meningkatkan kinerja guru sehingga tujuan pendidikan tercapai sesuai yang diharapkan.

2. Guru diharapkan dapat meningkatkan kinerjanya dengan baik.

3. Tata usaha diharapkan mendukung program kepala sekolah dalam meningkatkan kinerja guru di SDIT Ishlahul Ummah Kota Sawahlunto.

4. Lembaga pendidikan SDIT Ishlahul Ummah Kota Sawahlunto diharapkan selalu mempertahankan dan meningkatkan prestasi dibidang akademik maupun non akademik.

\section{KEPUSTAKAANACUAN}

Asmendri, (2012), Manajemen Peningkatan Mutu Pendidikan Sekolah/Madrasah, Batusangkar: Publising STAIN Batusangkar.

Departemen Agama RI, (2006), Al-Qur'an dan Tafsirnya, Jakarta: DIPA Bagian Litbang.

E.Mulyasa, (2012), Praktik Penelitian Tindakan Kelas, Bandung: PT. Remaja Rosdakarya.

Echols John dan Hasan Shadily. (2014) Kamus Inggris-Indonesia Edisi yang 
Diperbaharui. Jakarta: PT. Gramedia Pustaka Umum.

Hasibuan, (2006), Manajemen Sumber Daya Manusia, Jakarta: PT. Bumi Aksara.

Kamil, M. (2010), Model Pendidikan dan Pelatihan, Bandung: Alfabeta.

Lexi J Moleong, (2002), Metodologi Penelitian Kualitatif, Bandung: Remaja Rosdakarya.

Ramayulis, (1994), Ilmu Pendidikan Islam, Jakarta: Kalam Mulia.

Papalia, (2014), Menyelami Perkembangan Manusia, Jakarta: Salembah Humanika.

Purwanto Ngalim, (2010), Prinsip-Prinsip dan Teori Evaluasi Pengajaran, Bandung: PT. Remaja Rosdakarya.
Siagian, S.P (2003), Teori dan Praktek Kepemimpinan. Jakarta: Rineka Cipta

Simanjuntak, B. Pasaribu, (1990), Membina dan Mengembangkan Generasi Muda, Bandung: Tarsito.

Sugiyono, (2012), Memahami Penelitian Kualitatif, Bandung : Alfabeta.

Syafiie. (2011). Manajemen Pemerintah. Pustaka Reka Cipta Jawa Barat.

Usman Husaini, (2008), Manajemen (Teori Praktik dan Riset Pendidikan), Jakarta: Bumi Aksara.

Wahjosumidjo, (2012), Kepemimpinan Kepala Sekolah, Jakarta: PT Raja Grafindo Persada. 